\title{
Two more Bohemian trilobites from the Ordovician of Portugal and Morocco
}

\author{
isabel Rábano, Artur A. SÁ, Juan Carlos GutiérRez-Marco \& Diego C. García-Bellido
}

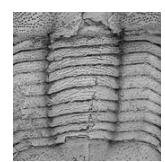

\begin{abstract}
Two trilobite species so far exclusive from the Dobrotivá Formation of the Prague Basin are reported for the first time outside Bohemia. The first is represented by a single specimen of Dindymene plasi Kielan, 1960 that occurs in Portugal within the Valongo Formation near Beloi, on the western flank of the Valongo Anticline (Central Iberian Zone). The second is Ectillaenus benignensis (Novák, 1918), recorded by eight articulated specimens which come from two different formations of the First Bani Group of the Moroccan eastern Anti-Atlas, located, respectively, in the upper part of the Guezzart Formation and near the top of the Ouine-Inirne Formation, both in the Jbel Bou Issidane section south of Alnif. All these occurrences are of Dobrotivian age (= late Darriwilian in the global timescale) and reinforce the palaeobiogeographical links within the north Gondwana platform. They are of special interest as it adds to a small group of species roughly coeval over a large area, and is of particular relevance for pre-Variscan palaeogeographic reconstructions. - Key words: Trilobites, Ordovician, Gondwana, palaeobiogeography, Iberia, Bohemia, Morocco.
\end{abstract}

RÁBAnO, I., SÁ, A.A., GutiérReZ-MARCO, J.C. \& GARCÍA-BELlido, D.C. 2010. Two more Bohemian trilobites from the Ordovician of Portugal and Morocco. Bulletin of Geosciences 85(3), 415-424 (3 figures). Czech Geological Survey, Prague. ISSN 1214-1119. Manuscript received December 29, 2009; accepted in revised form May 17, 2010; published online July 8, 2010; issued September 30, 2010.

Isabel Rábano, Museo Geominero, Instituto Geológico y Minero de España, Ríos Rosas 23, 28040 Madrid, Spain; i.rabano@igme.es. - Artur Abreu Sá, Departamento de Geologia, Universidade de Trás-os-Montes e Alto Douro, Ap. 1013, 5001-801 Vila Real, and Centro de Geociências da Universidade de Coimbra, Portugal; asa@utad.pt • Juan Carlos Gutiérrez-Marco \& Diego García-Bellido, Instituto de Geología Económica CSIC-UCM, Facultad de Ciencias Geológicas, José Antonio Nováis 2, 28040 Madrid, Spain; jcgrapto@geo.ucm.es,Diego.GBC@geo.ucm.es

The faunal correspondence between Iberia and Bohemia during the Ordovician has been recognized since the times of Verneuil \& Barrande (1855) and Delgado (1908), basically established through the existence of shared genera among many benthic invertebrate groups such as trilobites, echinoderms and molluscs. The evident faunal dynamics and palaeobiogeographical relationships between Iberia and Bohemia (Gutiérrez-Marco \& Rábano 1987, Gutiérrez-Marco et al. 1999) have even allowed the adoption of a common chronostratigraphic scale (Havlíček \& Marek 1973, Havlíček \& Fatka 1992), with Bohemian regional stages applicable in Iberia (Gutiérrez-Marco et al. 1995, 2002, Sá 2003, Gutiérrez-Marco et al. 2008, Bergström et al. 2009) as well as in the Moroccan Anti-Atlas (Gutiérrez-Marco et al. 2003).

The faunal provincialism of the European peri-Gondwana region becomes apparent in Ordovician trilobites even at the species level, with the presence in Oretanian to Kralodvorian strata of several Bohemian taxa also recognized in Iberia. These include: Hungioides bohemicus (Novák, 1918), Nobiliasaphus nobilis (Barrande, 1846), Parabarrandia crassa (Barrande, 1872), Prionocheilus mendax
(Vaněk, 1965), P. pulcher (Barrande, 1846), Selenopeltis macrophtalma (Klouček, 1916), S. vultuosa Přibyl \& Vaněk, 1966, S. buchi (Barrande, 1846), Colpocoryphe grandis (Šnajdr, 1956), Zetillaenus wahlenbergianus (Barrande, 1852) and Symphysops armata (Barrande, 1872); together with similar or closely related forms to Plaesiacomia rara Hawle \& Corda, 1847, Eccoptochile clavigera (Beyrich, 1845), Dalmanitina (D.) proaeva (Emmrich, 1839), Stenopareia oblita (Barrande, 1872) and Selenopeltis kamila Šnajdr, 1984: see Hammann (1974, 1976, 1983, 1992), Romano (1980, 1982, 1991), Rábano et al. (1983), Rábano (1989a-e) and Hammann \& Rábano (1987). In the context of southwestern Europe, a number of Oretanian to Berounian Bohemian trilobite species have also been described from the Armorican Massif (Cavet \& Pillet 1963; Henry 1980, 1989; Henry et al. 1997), Sardinia (Hammann \& Leone 1997, 2007), and to a lesser extent from the Moroccan Anti-Atlas, where affinities occur at a generic rather than specific level (Destombes 1966, 1972), with the relative exception of the widespread genus Selenopeltis (Bruton 2008). In Morocco, these similarities increase significantly in the Upper Ordovician, with 


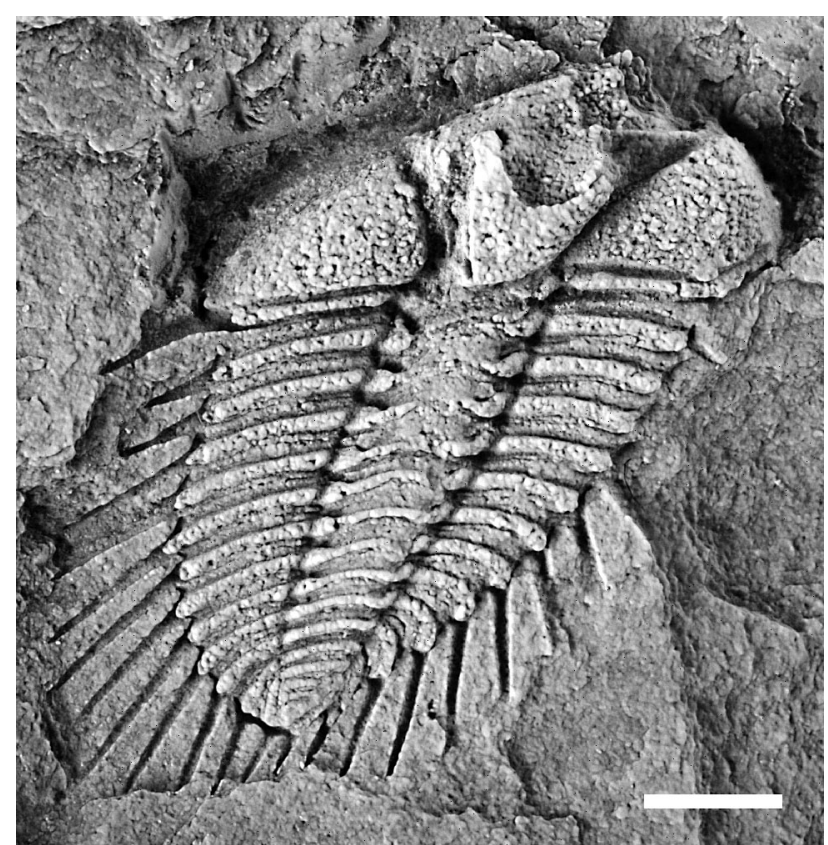

Figure 1. Dindymene plasi Kielan, 1960. Internal mould of a slightly deformed, articulated specimen from Beloi (northern Portugal), Valongo Formation, late early Dobrotivian (Da2) beds, top of the Placoparia (Coplacoparia) tournemini Biozone. Specimen housed in the Centro de Interpretación Geológica de Canelas (Arouca, Portugal), catalogue No. CIGC-1001. Scale bar $2 \mathrm{~mm}$.

the presence, among others, of Degamella princeps princeps (Barrande, 1872), Selenopeltis buchi (Barrande, 1846), S. vultuosa Přibyl \& Vaněk, 1966, Colpocoryphe grandis (Šnajdr, 1956), Prionocheilus pulcher (Barrande, 1846), Zdicella cf. zeidleri (Barrande, 1872), Dalmanitina (D.) socialis (Barrande, 1846), D. (D.) elfrida Šnajdr, 1982 (= D. proaeva sensu Destombes, 1972), Sokhretia aff. solitaria (Barrande, 1846), Eudolatites aff. dubius (Barrande, 1846) and Actinopeltis aff. grypha (Barrande, 1852).

The purpose of this paper is to report the discovery of two new Bohemian trilobites in the Middle Ordovician of Portugal and Morocco, respectively, which increases, at a species level, the palaeobiogeographical links previously proposed in the literature.

\section{Dindymene plasi from Portugal}

Dindymene is a rare encrinurid trilobite, represented by about twenty European and Asian species, each restricted to one or only a few localities in the British Isles, Bohemia, Bornholm, Poland, Pamir, Kazakhstan, China and the western Appalachians (Kielan 1960, Whittard 1960, Fortey \& Owens 1987, Neuman 1994, Kozák \& Vaněk 1997, Qiu et al. 1983 and references therein). Most of their representatives come from Upper Ordovician strata, whereas the genus is rare in the Middle Ordovician, with only four taxa described from the Fennian and Abereiddian of Britain, Llandeilo of Pamir and Dobrotivian of Bohemia.

Here we report the first occurrence of Dindymene from the Iberian Peninsula, represented by a minute blind Bohemian species, D. plasi Kielan, 1960, which is recognized for the first time outside the Prague Basin. The material consists of a single articulated specimen, slightly deformed and $10 \mathrm{~mm}$ long, preserved as an internal mould in argillaceous shale (Fig. 1). The cephalon has a semi-circular outline, with a strongly vaulted glabella expanding forward, and with anterior corners prolonged laterally. The posterior cephalic border is straight. The fixigenae are large, with a convex genal field, ending with genal spines directed very slightly backwards. The hypostome is poorly preserved below the anterior part of the glabella. The thorax is formed by ten segments, which gradually curve backwards towards the posterior. The rachis is defined by deep dorsal furrows and gradually tapers towards the posterior part. The distal pleural portions are free and extend as thin spines, directed obliquely on the first few segments and more posteriorly in the latter ones. The pygidium is small and narrow. The rachis is wide, reaching the posterior pygidial end, and exhibits at least four distinct rings and a poorly preserved terminal part. On the pleurae there are two ribs connected with the first and second axial rings, which also extend as spines, but shorter than the thoracic ones. The dorsal surface of the internal mould shows a coarse texture, indicative of an external ornamentation with granules and pits. Librigenae and axial spines on the glabella and the fourth thoracic ring are not preserved.

Figure 2. Ectillaenus benignensis (Novák, 1918) from the First Bani Group, eastern Anti-Atlas, Morocco. • A - natural external mould of a flattened, complete exoskeleton in dorsal view, MGM-6334-X $(\times 1.35) \cdot \bullet \mathrm{B}-$ cranidial region of the same specimen, showing details of the coarse ornamentation of the external surface and the smoother areas arranged in pairs, indicative of the position of glabellar and lateral muscle scars $(\times 2.1)$. $\bullet \mathrm{C}-$ pygidia of complete specimen MGM-6335-X with distinct axis and exfoliated doublure $(\times 1.9) \cdot \bullet \mathrm{D}, \mathrm{G}-$ internal mould of a partially complete exoskeleton in dorsal $(\mathrm{D}, \times 1.3)$ and lateral-left views $(\mathrm{G}, \times 2)$, specimen MGM-6338-X. $\bullet$ E - anterior part of the cephalon of specimen MGM-6337-X in ventral view, showing remains of the articulated rostral plate and part of the doublure of the right librigena $(\times 1) \cdot \bullet \mathrm{F}, \mathrm{H}, \mathrm{I}-$ complete specimen MGM-6336-X, with details of cephalon in frontal view showing librigenae pointing downwards $(\mathrm{F}, \times 0.9)$, cephalon in lateral-right view with suture and rounded end of librigena $(\mathrm{H}, \times 1.1)$, and exoskeleton in lateral-left view showing ventral doublures of pygidium and librigena $(\mathrm{I}, \times 1)$. Specimens Dand $\mathrm{G}$ come from locality 1826 in the upper part of the Guezzart Formation; the remaining specimens are from locality 1825, located near the top of the Ouine-Inirne Formation. Both localities lie in the Jbel Bou Issidane area south of Alnif and are of Dobrotivian (late Darriwilian) age. All material belongs to the collection of the Museo Geominero in Madrid, Spain. 
Isabel Rábano et al. - Two more Bohemian trilobites from the Ordovician of Portugal and Morocco
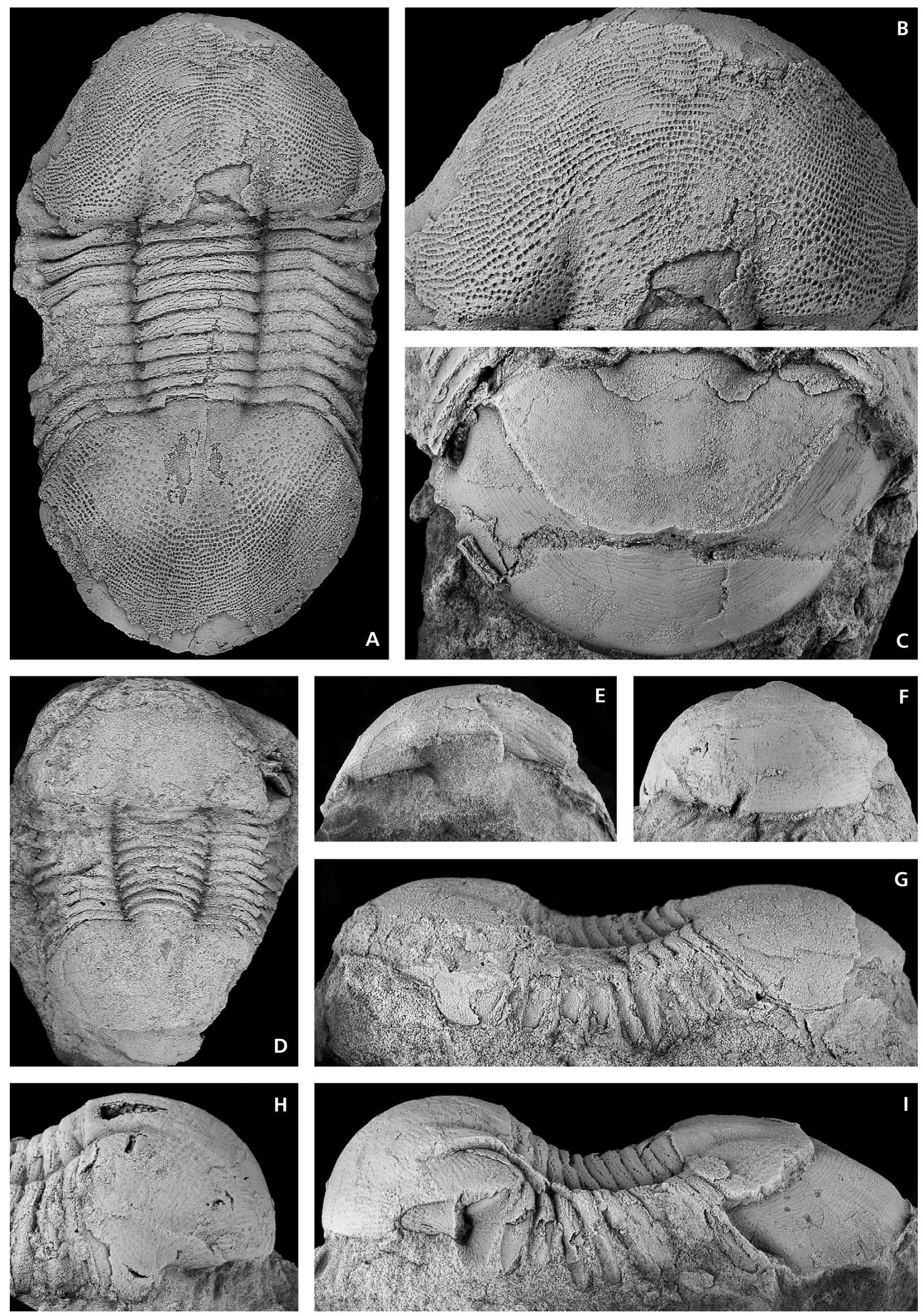
The Portuguese specimen was found in the classic trilobite locality near Beloi, about $12 \mathrm{~km}$ east of the city of Oporto. The fossil locality was discovered by Delgado (1908) and is mentioned, among others, by Romano (1991, text-fig. 1), who provided a location map. According to this author and our own data, the trilobite horizons are located towards the upper part of the Valongo Formation (Romano \& Diggens 1974), belonging to the uppermost part of the Placoparia (Coplacoparia) tournemini Biozone, in beds dated as latest early Dobrotivian age (= late Darriwilian on the global scale, see GutiérrezMarco et al. 2008).

Dindymene plasi Kielan, 1960 is a rare Bohemian trilobite, so far only described from a few localities in the Dobrotivá Formation (Dobrotivian) from the whole Barrandian area. However, their type specimens (Kielan 1960) supposedly came from older horizons of the Šrka Formation (late Arenigian to Oretanian), but Šnajdr (1990) and Kozák \& Vaněk (1997) have observed that the localities mentioned by Kielan in fact belong to the Dobrotivá Formation. The Portuguese record of this species is thus approximately of the same age as the typical Bohemian specimens, which clearly differ from the remaining Dindymene species in the shape of the cephalon and pygidium, and by the comparatively short, thin genal, thoracic and pygidial spines.

The occurrence of Dindymene plasi in the Valongo Formation adds to that of Dobrotivian cheirurids such as Actinopeltis (Valongia) wattisoni Curtis, 1961, Eccoptochile (E.) almadenensis Romano, 1980, E. (E.?) mariana (Verneuil \& Barrande, 1855) and E. (E.) cf. clavigera (Beyrich, 1845), described from the Valongo Formation by Curtis (1961), Romano $(1980,1991)$ and Tauber et al. (1997). All of these taxa have early meraspid stages with a "spinose" aspect resembling adult specimens of Dindymene plasi, of average length $10-15 \mathrm{~mm}$. However, D. plasi is easily recognizable by the characteristic shape of its glabella, comparatively smaller than that of the meraspid stages of the other cheirurid species, and also by its segmented pygidial rachis. Spinosity is also very different in the mentioned cheirurids (see for instance, Rábano 1989c, pl. 28, fig. 7 for Eccoptochile).

\section{Ectillaenus benignensis from Morocco}

Ectillaenus is the most common illaenid trilobite occurring in the European peri-Gondwanan realm. It is known from eleven species, mainly described from Britain (Whittard 1961, Fortey \& Owens 1987), Ibero-Armorica (Rábano \& Gutiérrez-Marco 1983, Rábano 1989e), Germany (Budil et al. 2009) and Bohemia (Šnajdr 1957, Bruthansová 2003). Outside Europe, the genus has only been reported from Morocco (Termier \& Termier 1950, Destombes et al. 1985), but so far all the specimens were listed as Ectillaenus sp. with the exception of a specimen from the western High Atlas and being related to E. perovalis (Murchison, 1839) (Termier \& Termier 1950, pl. 193, figs 15-17). Doubtful records of Ectillaenus have also been listed from China (Zhou \& Zhen 2008) and Kirghizistan (Petrunina in Repina et al. 1975).

The general biostratigraphical review by GutiérrezMarco et al. (2003) of the Middle Ordovician formations of the Moroccan Anti-Atlas produced new material in the localities numbered as 1825 and 1826 by Destombes (1985), also including some echinoderms (Chauvel 1978) and molluscs (Babin \& Destombes 1990). Among the trilobites we could identify several specimens of Ectillaenus benignensis (Novák, 1918), which represent the first record of this species outside Bohemia.

The Moroccan E. benignensis material consists of eight articulated specimens, four of them exceptionally well preserved as natural external moulds in calcareous siltstone, one as a concave internal mould and three internal moulds (Figs 2, 3). The main specific characters are easily recognizable: a coarse ornamentation of large pits arranged mostly in rows which cover almost the complete dorsal surface of the vaulted carapace, but is attenuated in the pygidial rachis and in the cephalic muscle fields; semi-circular cephalon lacking eyes; librigenae narrow and with a prominent rounded end pointing downwards; pygidium moderately parabolic in outline, with axis occasionally distinct in some internal moulds, reaching $40 \%$ of the pygidial length; pygidial doublure extending for almost half of the pygidial length (sag.).

Ectillaenus benignensis is the most coarsely ornamented species of the genus (Novák 1918, Šnajdr 1984, Bruthansová 2003). In this aspect, it resembles only

Figure 3. Ectillaenus benignensis (Novák, 1918) from the First Bani Group, eastern Anti-Atlas, Morocco. • A, I - internal mould of a partially complete exoskeleton, MGM-6340-X, in dorsal view $(\mathrm{A}, \times 1.3)$ and detail of the cephalon, suture and librigena in lateral-right view $(\mathrm{I}, \times 2.66)$. $\bullet \mathrm{B}-$ latex cast from the external mould, dorsal view, MGM-6341-X $(\times 1.3)$. $\bullet$, E, F, J - natural external mould of the complete specimen MGM-6337-X in dorsal $(\mathrm{C}, \times 1)$ and lateral-right views $(\mathrm{E}, \times 1.26)$, with details of the cephalic suture and strong ornamentation of the right librigena in oblique-lateral view $(\mathrm{F}, \times 2.3)$ and the second to fourth thoracic segments $(\mathrm{J}, \times 2)$. $-\mathrm{D}$ - details of the external ornamentation of the last eight thoracic segments of the specimen MGM-6336-X (× 1.8), see also Fig. 2F, H, I. • G, H - internal mould of a partially complete exoskeleton, MGM-6339-X, in dorsal view showing doublures on the thoracic pleurae $(\mathrm{G}, \times 1.1)$, and detail of the cephalon with muscle scars and suture, in oblique anterolateral view $(\mathrm{H}, \times 1.46)$. Specimens $\mathrm{C}-\mathrm{F}$ and $\mathrm{J}$ come from locality 1825 near the top of the Ouine-Inirne Formation; remaining specimens are from locality 1826 in the upper part of the Guezzart Formation. Both localities lie in the Jbel Bou Issidane area south of Alnif, and are of Dobrotivian (late Darriwilian) age. All material belongs to the collection of the Museo Geominero in Madrid, Spain. 
Isabel Rábano et al. - Two more Bohemian trilobites from the Ordovician of Portugal and Morocco
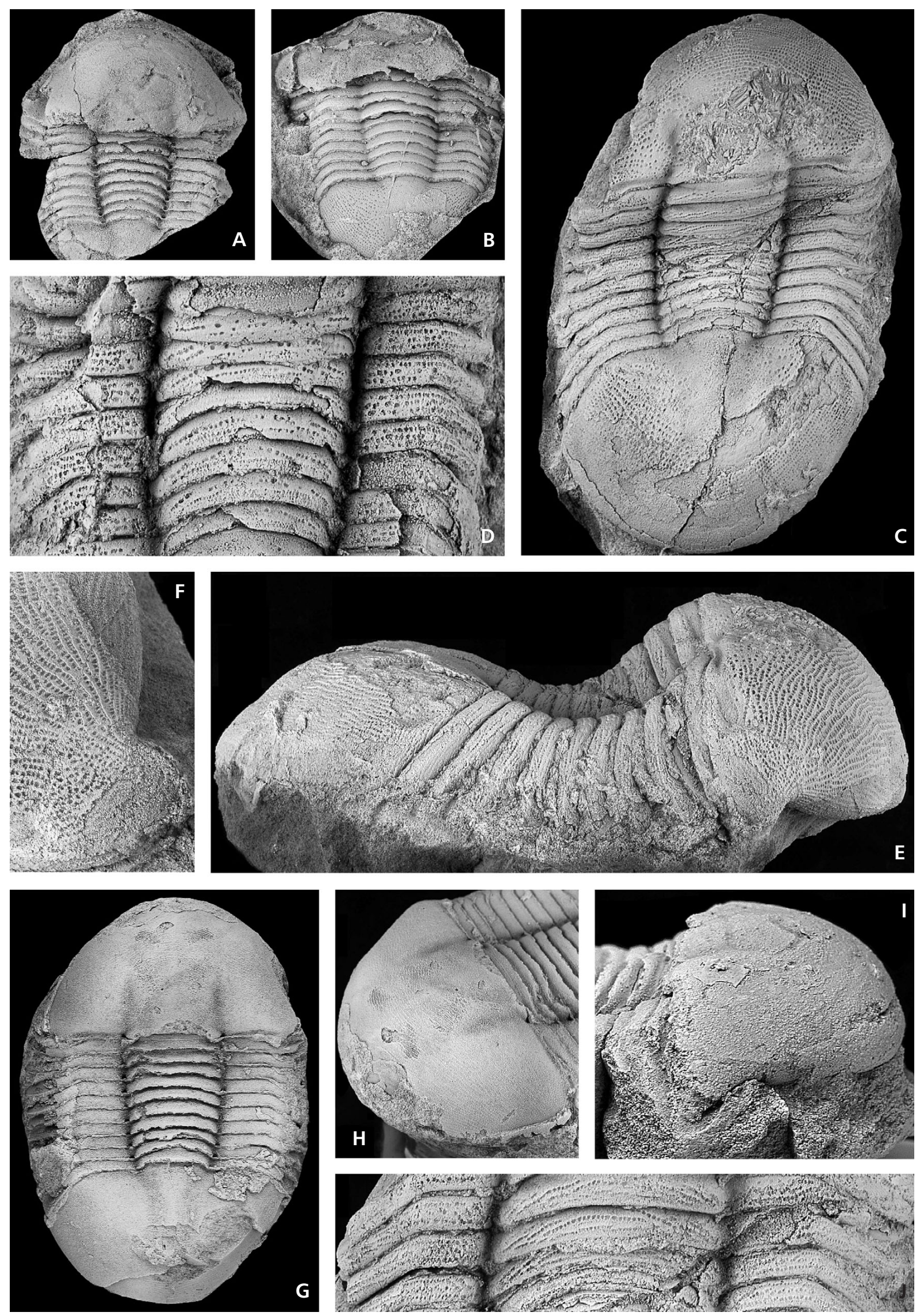
E. "hughesii" (Hicks, 1875) [= E. perovalis (Murchison, 1839)], and both taxa were considered synonyms by Whittard (1940, 1961) and Pek \& Vaněk (1989). However, Šnajdr (1957) convincingly demonstrated the differences between the British and Bohemian forms, and E. benignensis was recognized as a separate species also by Rábano \& Gutiérrez-Marco (1983), Fortey \& Owens (1987), Bruthansová (2003), Budil (1999) and Vaněk \& Valíček (2001).

From a biostratigraphical point of view, E. benignensis is recognized from the whole Barrandian area within the Dobrotivá Formation (Dobrotivian, essentially upper Darriwilian). The Moroccan record is also Dobrotivian in age, and includes two different formations in the First Bani Group of the eastern Anti-Atlas. The specimens MGM-6338-X to MGM-6341-X (Figs 2D, G, 3A, B, G-I), come from the Destombes' locality 1826, located towards the upper part of the Guezzart Formation in the Jbel Bou Issidane area south of Alnif (geological map of Morocco, sheet Alnif to $1: 100,000$ scale, Lambert coordinates $\mathrm{x}=$ 521.5; $y=45.8)$. The specimens occur in fine calcareous sandstones associated with other trilobites (Selenopeltis sp., Placoparia (Coplacoparia) sp.), as well as with some diploporite echinoderms (Calix, Phlyctocystis and Isidalocystis). This locality, previously assigned to the Taddrist Formation by Chauvel (1978), was reviewed by Gutiérrez-Marco et al. (2003) and reassigned to the Guezzart Formation in beds of late early Dobrotivian age. The second fossiliferous locality provided another four specimens of E. benignensis, even better preserved, from calcareous and ferruginous sandstone. These were numbered MGM-6334-X to MGM-6337-X (Figs 2A-C, E, F, H-I, 3C-F, J). It corresponds to locality 1825, which lies very close to the former locality (geological map of Morocco, sheet Alnif to 1 : 100,000 scale, Lambert coordinates $\mathrm{x}=523.3$; $\mathrm{y}=45.8$ ), but in higher beds, occurring near the top of the Ouine-Inirne Formation. Apart from Ectillaenus, several other trilobite genera occur in the association (Selenopeltis sp., Eccoptochile sp., Placoparia sp.), as well as some molluscs (Babin \& Destombes 1990). According to Gutiérrez-Marco et al. (2003), the locality has a late Dobrotivian age, but still within the latest Darriwilian.

\section{Palaeobiogeographical relationships}

The discovery of Dindymene plasi Kielan, 1960 in the Ordovician of Portugal is of prime importance because it increases the group of such Dobrotivian Ibero-Bohemian species which are roughly coeval in both areas and whose appearance is not related to the global mid Darriwilian transgression. In addition to the present form, the group also includes the benthic trilobites Placoparia (Coplacoparia) borni Hammann, 1971 [= P. (C.) antiopa Moravec,
1990 according to Havlíček \& Vanek 1996] and Eccoptochile mariana Verneuil \& Barrande, 1855 [= E. vipera Moravec, 1986 according to Havlíček \& Vanek 1996 and Vanek \& Valíček 2001], both recorded from the late Dobrotivian; the nektobenthic Parabarrandia crassa (Barrande, 1872), sporadically represented in some late early Dobrotivian localities of Ibero-Armorica; the diploporid Calix purkynei (Klouček, 1917), which occurs in the earliest Dobrotivian of Spain and at a single Bohemian locality, and the cephalopod Trocholites fugax (Babin \& Gutiérrez-Marco, 1992). The latter is linked to a common episode of climatic disturbance in northern Gondwana (Babin \& Gutiérrez-Marco 1992, Manda 2008). Similarly, the discovery of Ectillaenus benignensis (Novák, 1918) in the Dobrotivian of Morocco represents the first fully benthic trilobite apparently coeval in North Africa and Bohemia during the late Darriwilian, apart from some of the nekto-benthic species of Selenopeltis reported by Bruton (2008).

According to Gutiérrez-Marco et al. (1999), the first generic, and even specific, similarity between IberoArmorican and Bohemian faunas starts by the end of the Arenigian, influenced by the global mid Darriwilian transgression. This is exemplified among the Oretanian faunas by the common occurrence of Placoparia (P.) cambriensis Hicks, 1875 (= Placoparia barrandei Prantl \& Šnajdr, 1957), Hungioides bohemicus (Novák, 1918), Selenopeltis macrophtalma (Klouček, 1916), Babinka prima Barrande, 1881, Redonia deshayesi Rouault, 1851 (= R. bohemica Barrande, 1881), Coxiconchia britannica (Rouault, 1851) [= C. b. holubi Kříž, 1995], Lagynocystis pyramidalis Barrande, 1887, Palaeura neglecta Schuchert, 1915, among others; or by the trilobite genera Asaphellus, Nobiliasaphus, Bathycheilus, Colpocoryphe, Ectillaenus, Dionide, Geragnostus, Toletanaspis or Uralichas. Some of these faunas were previously recorded in the Arenigian of Eastern Avalonia, SW France, as well as in the North African and South American margins of Gondwana (Gutiérrez-Marco \& Rábano 1987, Gutiérrez-Marco et al. 1999). However, after the end of the influx of this global transgression, the Dobrotivian faunas abruptly decrease in similarity, with the only exceptions being the coeval taxa listed above, to which D. plasi in SW Europe and E. benignensis in $\mathrm{N}$ Africa are now added.

The chronostratigraphic refinement achieved in the Mediterranean regional scheme for the Middle and Upper Ordovician, allowed the recognition of a considerable diachronism in the appearance of another set of benthic to epiplanktic taxa in common between Iberia and Bohemia. The pattern was recognized among taxa recorded from the Iberian Oretanian, whose first appearance in Bohemia took place in the Dobrotivian (such as the brachiopod Brandysia benigna Havlíček, 1975), or those Oretanian or Dobrotivian Iberian taxa with delayed presence in Bohemia until 
the Berounian or Kralodvorian. These include the trilobites Colpocoryphe grandis (Šnajdr, 1956) and Nobiliasaphus nobilis (Barrande, 1846) s.l., the ostracod Quadritia (Krutatia) tromelini Vannier \& Schallreuter, 1983, the molluscs Myoplusia bilunata perdentata (Barrande, 1881) and Technophorus sharpei (Barrande in Perner, 1903), the echinoderms Aristocystites metroi Parsley \& Prokop in Parsley, 1990, A. bohemicus Barrande, 1887, Codiacystis moneta (Barrande, 1887) s.l. and C. aff. bohemica (Barrande, 1887), the hyoliths Leolites, Andalucilites and Recilites and the brachiopod genera Jezercia and Aegiromena, among others. The existence of the above-mentioned taxa, appearing earlier in Iberia than in Bohemia, led Gutiérrez-Marco et al. (1999) to propose the existence of an apparent one-way migration route already established by the Middle Ordovician running eastwards from Ibero-Armorica to Bohemia.

\section{Concluding remarks}

The classic biogeographical relationships between Bohemia with Ibero-Armorica and Morocco have long been interpreted as a result of free faunal exchange, which could have operated simultaneously in all directions within the North African and European peri-Gondwana environment. This would imply an established geographic continuity, with faunal differences explained in terms of bathymetric facies, which, for instance, would have prevented the dispersal of the inshore Neseuretus Fauna into the deeper Bohemian environments dominated by atheloptic communities during the Middle Ordovician. However, the paleogeography of the peri-Gondwanan areas of Europe and North Africa was more complex than previously understood, and refutes a direct continuity between Iberia and Bohemia before being obscured and overwritten by Variscan tectonics. The more recent and conflicting paleogeographical models (Robardet 2003, Carls 2003, Cocks \& Torsvik 2006, Nance \& Linnemann 2008, von Raumer \& Stampfli 2008) need to be checked against the paleontological record and, in this context, the new Bohemian trilobites shared with Portugal and Morocco should be taken into account in any future and more precise palaeobiogeographical reconstruction.

\section{Acknowledgements}

We are indebted to Manuel Valério (Canelas, Portugal), who provided the specimen of $D$. plasi for our study, Zhou Zhiyi (Nanjing, China) for valuable information regarding the Chinese species of Dindymene, and our colleague Carlos Alonso (Madrid) for the photographs. We thank Alan Owen (Glasgow) and Olda Fatka (Prague) for their detailed and constructive criticism of this paper. This is a contribution to project CGL2009-09583 of the Spanish Ministry of Science and Innovation and to IGCP Project 503 "Ordovician Palaeogeography and Palaeoclimate".

\section{References}

BABin, C. \& Destombes, J. 1990. Les Mollusques Bivalves et Rostroconches ordoviciens de l'Anti-Atlas marocain: Intérêt paléogéographique de leur inventaire. Géologie Méditerranéenne 17, 243-261.

BABIN, C. \& GUTIÉRREZ-MARCO, J.C. 1992. Intérêt paléobiogeographique de la présence du genre Trocholites (Cephalopoda, Nautiloidea) dans le Dobrotivá (Llandeilo) inférieur d'Espagne. Neues Jahrbuch für Geologie und Paläontologie Monatshefte 1992(9), 519-541.

BARRANDE, J. 1846. Notice préliminaire sur le système silurien et les trilobites de Bohême. i-vi, 97 pp. Hirschfeld, Leipzig.

BARRANDE, J. 1852. Systême silurien du centre de la Bohême. $1^{\text {ère }}$ partie: Recherches Paléontologiques. Vol. I. Crustacés: Trilobites. i-xxx, 935 pp. Chez l'auteur et éditeur, Prague.

BARRANDE, J. 1872. Système silurien du centre de la Bohême. Vol. I, Suppl. I, Systême silurien du centre de la Bohême. $1^{\text {ère }}$ partie: Recherches Paléontologiques. Supplément au Vol. I. Trilobites, Crustacés divers et Poissons. 647 pp. Chez l'auteur et éditeur, Imprimerie de Charles Bellmann, Prague.

BARRANDE, J. 1887. Systême silurien du centre de la Bohême. $I^{\text {ère }}$ partie: Recherches Paléontologiques. Vol. VII. Classe des Échinodermes. Ordre des Cystidées. 233 pp. Řivnáč, Prague \& Gerhard, Leipzig.

BergströM, S.M., CHEN, X., GutiéRreZ-MARCO, J.C. \& DroNOV, A.V. 2009. The new chronostratigraphic classification of the Ordovician System and its relations to major regional series and stages and $\delta^{13} \mathrm{C}$ chemostratigraphy. Lethaia $42(1)$, 97-107. DO1 10.1111/j.1502-3931.2008.00136.x

BEYRICH, E. 1845. Untersuchungen über Trilobiten. Zweites Stück als Fortsetzung zu der Abhandlung: Über einige böhmische Trilobiten. 47 pp. G. Reimer, Berlin.

BRUTANSOVÁ, J. 2003. The trilobite Family Illaenidae Hawle et Corda, 1847 from the Ordovician of the Prague Basin (Czech Republic). Transactions of the Royal Society of Edinburgh 93 (for 2002), 167-190.

BRUTON, D.L. 2008. A systematic revision of Selenopeltis (Trilobita: Odontopleuridae) with description of new material from the Ordovician Anti Atlas region, Morocco. Paläontologische Zeitschrift 82(1), 1-16.

BUDIL, P. 1999. Nový výchoz dobrotivského souvrství v Praze-Vokovicích (střední ordovik). Journal of the Czech Geological Society 44(1-2), 195-199.

Budil, P., FATKA, O., KRAFT, P., SÁ, A., LinnemanN, U. \& MAREK, J. 2009. Předběžná zpráva o faunistických asociacích sasko-durynského nejvyššího spodního a středního ordoviku. (Preliminary report on the faunal associations of the uppermost Lower and Middle Ordovician of the Saxo-Thuringian region). Zprávy o geologických výzkumech (Geosciences Research reports for 2008), 85-87.

CARLS, P. 2003. Tornquist's Sea and the Rheic Ocean are illusive. Courier Forschungs-Institut Senckenberg 242, 89-109. 
Cavet, P \& Pillet, J. 1963. Contribution à létude stratigraphique et paléontologique du synclinal d'Ancenis (massif armoricain). Bulletin de la Société Géologique de France [7] 5(2), 318-330.

Chauvel, J. 1978. Compléments sur les Echinodermes du Paléozoïque marocain (Diploporites, Eocrinoïdes, Edrioastéroïdes). Notes et Mémoires du Service Géologique du Maroc 39(272), 27-78.

COCKS, L.R.M. \& TORSVIK, T.H. 2006. European geography in a global context from the Vendian to the end of the Palaeozoic, 83-95. In GEE, D.G. \& STEPHENSON, R.A. (eds) European Lithosphere Dynamics. Memoirs of the Geological Society of London 32.

CURTIS, M.L.K. 1961. Ordovician trilobites from the Valongo area, Portugal. Cheiruridae, Pliomeridae and Dionididae. Boletim da Sociedade Geológica de Portugal 14, 1-16.

DELGADO, J.F.N. 1908. Système Silurique du Portugal. Étude de stratigraphie paléontologique. Mémoire de la Commission du Service Géologique du Portugal, 1-245.

Destombes, J. 1966. Quelques Calymenina (Trilobitae) de l'Ordovicien moyen et supérieur de l'Anti-Atlas (Maroc). Notes et Mémoires du Service Géologique du Maroc 26(188), 33-53.

Destombes, J. 1972. Les trilobites du sous-ordre des Phacopina de l'Ordovicien de l'Anti-Atlas (Maroc). Notes et Mémoires du Service Géologique du Maroc 32(240), 1-114.

Destombes, J. 1985. Notice explicative (Cambrien moyen, Ordovicien, base du Silurien) de la Carte géologique du Maroc au 200 000e de l'Anti-Atlas marocain. Chapitre D: Feuilles Todhra-Maïder. Rapport Interne du Service de la Carte géologique du Maroc, Rabat (unpubl.).

Destombes, J., Hollard, H. \& Willefert, S. 1985. Lower Palaeozoic rocks of Morocco, 91-336. In Holland, C.H. (ed.) Lower Palaeozoic Rocks of the World, vol. 4. Lower Palaeozoic of north-western and west central Africa. John Wiley and Sons, Chichester.

EMMERICH, H.F. 1839. De trilobitis: dissertatio petrefactologica quam consensu et auctoritate amplissimi philosophorum ordinis in alma litterarum universitate Friderica Guilelma pro summis in philisophia honoribus. 56 pp. Typis Nietackianis, Berlin.

FORTEY, R.A. \& OWENS, R.M. 1987. The Arenig Series in South Wales. Bulletin of the British Museum natural History (Geology) 41(3), 69-307.

GutiérReZ-Marco, J.C., Destombes, J., ACEÑOlaZA, F.G., SARMIENTO, G.N., RÁBANO, I. \& SAN JoSÉ, M.A. DE 2003. El Ordovícico Medio del Anti-Atlas marroquí: paleobiodiversidad, actualización bioestratigráfica y correlación. Geobios 36(2), 151-177. DOI 10.1016/S0016-6995(03)00004-4

GutiÉRREZ-MARCO, J.C. \& RÁBANO, I. 1987. Paleobiogeographical aspects of the Ordovician mediterranean faunas. Geogaceta 2, 24-26.

Gutiérrez-Marco, J.C., RÁbano, I., SAN José, M.A., HerRANZ, P. \& SARMIENTO, G.N. 1995. Oretanian and Dobrotivian stages vs. "Llanvirn-Landeilo" Series in the Ordovician of the Iberian Peninsula, 55-59. In COOPER, J.D., DROSER, M.L. \& FInNEY, S.C. (eds) Ordovician Odyssey. Pacific Section Society for Sedimentary Geology 77, Fullerton.

Gutiérrez-Marco, J.C., RÁbano, I., SARmiento, G.N.,
Aceñolaza, G.F., San José, M.A., Pieren, A.P., HerRANZ, P., COUTO, H.M. \& PIÇARRA, J.M. 1999. Faunal dynamics between Iberia and Bohemia during the Oretanian and Dobrotivian (late Middle-earliest Upper Ordovician), and biogeographic relations with Avalonia and Baltica. Acta Universitatis Carolinae, Geologica 43, 487-490.

GutiÉRrez-Marco, J.C., Robardet, M., RÁbANO, I., SARMIENTO, G.N., SAN JOSÉ LANCHA, M.A., HERRANZ ARAúJO, P. \& PIEREN PIDAL, A.P. 2002. Chapter 4: Ordovician, 31-47. In Gibbons, W. \& Moreno, M.T. (eds) The Geology of Spain. The Geological Society, London.

GuTIÉRREZ-MARCO, J.C., SÁ, A.A. \& RÁBANO, I. 2008. Ordovician time scale in Iberia: Mediterranean and global correlation, 46-49. In Development of Early Paleozoic biodiversity: role of biotic and abiotic factors, and event correlation. KMK Scientific Press, Moscow.

HAMmANN, W. 1971. Die Placopariinae (Trilobita, Cheirurina, Ordovizium). Senckenbergiana lethaea 52(2), 53-75.

HAMmanN, W. 1974. Phacopina und Cheirurina (Trilobita) aus dem Ordovizium von Spanien. Senckenbergiana lethaea 53(1-4), 1-151.

HammanN, W. 1976. Trilobiten aus dem oberen Caradoc der östlichen Sierra Morena (Spanien). Senckenbergiana lethaea 57(1), 35-85.

HammanN, W. 1983. Calymenacea (Trilobita) aus dem Ordovizium von Spanien; ihre Biostratigraphie, Ökologie und Systematik. Abhandlungen der Senckenbergischen Naturforschenden Gesellschaft 542, 1-177.

HAMMANN, W. 1992. The Ordovician trilobites from the Iberian Chains in the province of Aragón, NE-Spain. I. The trilobites of the Cystoid Limestone (Ashgill Series). Beringeria 6, 3-219.

HAMmanN, W. \& LeONE, F. 1997. Trilobites of the post-Sardic (Upper Ordovician) sequence of southern Sardinia. Part I. Beringeria 20, 3-217.

HAMmANN, W. \& LEONE, F. 2007. Trilobites from the postSardic (Upper Ordovician) sequence of southern Sardinia. Part 2. Beringeria 38, 3-138.

HAMMANN, W. \& RÁBANO, I. 1987. Morphologie und Lebensweise der Gattung Selenopeltis (Hawle \& Corda, 1847) und ihre Vorkomenn im Ordovizium von Spanien. Senckenbergiana lethaea $68,91-137$.

HAVLÍČEK, V. 1975. New genera and species of Orthida (Brachiopoda). Vestník Ústředního ústavu geologického 50, 231-235.

HAVLÍČEK, V. \& FATKA, O. 1992. Ordovician of the Prague Basin (Barrandian area, Czechoslovakia), 461-472. In WEBBY, B.D. \& LAURIE, J.R. (eds) Global Perspectives on Ordovician Geology. Balkema, Rotterdam.

HAVLÍČEK, V. \& MAREK, L. 1973. Bohemian Ordovician and its international correlation. C̆asopis pro mineralogii a geologii $18,225-232$.

HAVLÍČEK, V. \& VANĚK, J. 1996. Dobrotivian/Berounian boundary interval in the Prague Basin with a special emphasis on the deepest part of the trough (Ordovician, Czech Republic). Vestník Českého geologického ústavu 71(3), 225-243.

HAWLE, I. \& CORDA, A.J.C. 1847. Prodrom einer Monographie der böhmischen Trilobiten. 176 pp. Calve, Prague.

HENRY, J.-L. 1980. Trilobites ordoviciens du Massif Armoricain. 
Mémoire de la Société Géologique et Minéralogique de Bretagne 22, 1-250.

HENRY, J.-L. 1989. Paléoenvironements et dynamique de faunes de trilobites dans l'Ordovicien (Llanvirn Supérieur-Caradoc basal) du Massif Armoricain (France). Palaeogeography, Palaeoclimatology, Palaeoecology 73, 139-153.

HENRY, J.-L., LEFEBVRE, B. \& CHAUVIN, D. 1997. Stratification thermique probable des eaux marines sur la marge gondwanienne (Massif Armoricain) pendant l'Ordovicien (Llanvirn): Implications paléogéographiques. Neues Jahrbuch für Geologie und Paläontologie Abhandlungen 205(3), 373-392.

HICKS, H. 1875. On the succesion of the ancient rocks in the vicinity of St. David's, Pembrokeshire, with special reference to those of Arenig and Llandeilo groups, and their fossil contents. Quaterly Journal of the Geological Society of London 31, 167-195.

KIELAN, Z. 1960. Upper Ordovician trilobites from Poland and some related forms from Bohemia and Scandinavia. Palaeontologia Polonica 11 (for 1959), 1-198.

KLOUČEK, C. 1916. O vrstvách $\mathrm{D}_{1 \gamma}$, jich trilobitech a nalezištích. Rozpravy České akademie císaře Františka Josefa pro vědy, slovesnost a umění, Třída II (mathematicko-přirodovědecká) 25(39), 1-21.

KLOUČEK, C. 1917. Nová cystidea z d $\mathrm{d}_{1} \gamma$. Rozpravy České akademie císaře Františka Josefa pro vědy, slovesnost a umění, Tř́ida II (mathematicko-přirodovědecká) 26(17), 1-4.

KoZÁK, V. \& VANĚK, J. 1997. Dindymene kenchrias n. sp. (Trilobita) in the Vinice Formation (Berounian Stage, Ordovician) of the Prague Basin, Czech Republic. Palaeontologia Bohemiae 3(4), 10-12.

KŘíž, J. 1995. Coxiconchia Babin, 1966 from the Llanvirn of the Prague Basin (Bivalvia, Ordovician, Bohemia) and the function of some "accessoric" muscles in Recent and fossil Bivalvia. Vestník Českého geologického ústavu 70(2), 45-50.

MANDA, S. 2008. Trocholites Conrad, 1838 (Nautiloidea, Tarphycerida) in the Middle Ordovician of the Prague Basin and its palaeobiogeographical significance. Bulletin of Geosciences 83(3), 327-334.

MORAVEC, J. 1986. New trilobites from the Šárka and Dobrotivá Formations in the western part of the Barrandian area. Věstník Ústředního ústavu geologického 61(6), 367-370.

MORAVEC, J. 1990. Three new placopariid trilobites from the Bohemian Ordovician. Věstník Ústředního ústavu geologického 65(2), 75-80.

MURCHISON, R.I. 1839. The Silurian System, founded on geological researches in the counties of Salop, Hereford, Radnor, Montgomery, Caermarthen, Brecon, Pembroke, Monmouth, Gloucester, Worcester and Stafford; with descriptions of the coal-fields and overlying formations. i-xxxii, $768 \mathrm{pp}$. John Murray, London.

NANCE, R.D. \& LiNNEMANN, U. 2008. The Rheic Ocean: Origin, evolution and significance. GSA Today 18(12), 4-12.

NEUMAN, R.B. 1994. Late Ordovician (Ashgill) Foliomena fauna brachiopods from the northeastern Maine. Journal of Paleontology 68(6), 1218-1234.

NovÁK, O. 1918. Trilobiti pásma D-d $\mathrm{d}_{1 \gamma}$ z okolí pražského, rukopisná studie k tisku upravil a doplňky opatřil Jaroslav Perner. Palaeontographica Bohemiae 9, 1-51.
PARSLEY, R. 1990. Aristocystites, a recumbent diploporid (Echinodermata) from the Middle and Late Ordovician of Bohemia, ČSSR. Journal of Paleontology 64(2), 278-293.

PERNER, J. 1903. Gastéropodes, i-xi, 1-164. In BARRANDE, J. Systême silurien du centre de la Bohême. Vol. 4(1). Prague.

PEK, I. \& VANĚK, J. 1989. Index of Bohemian trilobites. 68 pp. Krajské vlastivědné museum, Olomouc.

PRANTL, F. \& ŠNAJDR, M. 1957. Studie o rodu Placoparia Hawle a Corda (Trilobitae). Sborník Ústředního ústavu geologického, Oddíl paleontologický 23(1956), 497-521.

PŘIBYL, A. \& VANĚK, J. 1966. Neue Trilobiten des böhmischen Ordoviziums. Věstník Ústředního ústavu geologického 40(4), 277-282.

QIU, H., LU, Y., ZHU, Z-1., BI, D., LIN, T., ZHOU, Z-Y., ZHANG, Q., QIAN, Y., JU, T., HAN, N. \& WEI, X. 1983. Trilobita, 28-254. In Palaeontological Atlas of East China (1). Geological Publishing House, Beijing.

RÁBANO, I. 1989a-e. Trilobites del Ordovícico Medio del sector meridional de la Zona Centroibérica española. Boletín Geológico y Minero 100, 307-338 (part 1), 541-609 (part 2), 767-841 (part 3), 971-1032 (part 4). Reprinted in 1990 as: Publicaciones Especiales del Boletín Geológico y Minero, $1-233$.

RÁBANO, I. \& GUTIÉRREZ-MARCO, J.C. 1983. Revisión del género Ectillaenus Salter, 1867 (Trilobita, Illaenina) en el Ordovícico de la Península Ibérica. Boletín de la Real Sociedad Española de Historia Natural (Geología) 81(3-4), 225-246.

RePINA, L.N., YASKOVICH, B.V., AKSARINA, N.A., PETRUNINA, Z.E., PONILENKO, I.A., RubANOV, D.A., BOlgOVA, G.V., Golikov, A.N., HaJRUllina, T.I. \& POSOChOVA, M.M. 1975. Stratigrafiya i fauna nizhnego paleozoya severnykh predgoriy Turkestanskogo i Alayskogo khrebtov (yuzhniy Tyan'-Shan). Akademiya Nauk SSSR, Sibirskoe Otdelenie. Institut Geologii i Geofiziki Novosibirsk, Trudy 278, 1-351.

RouAult, M. 1851. Mémoire sur le terrain paléozoique des environs de Rennes. Bulletin de la Société Géologique de France [2] 8, 358-399.

RoBARDET, M. 2003. The Armorican 'microplate': fact or fiction? Critical review of the concept and contradictory palaeobiogeographical data. Palaeogeography, Palaeoclimatology, Palaeoecology 195, 125-148.

DOI 10.1016/S0031-0182(03)00305-5

ROMANO, M. 1980. The trilobite Eccoptochile from the Ordovician of northern Portugal. Palaeontology 23(3), 605-616.

Romano, M. 1982. A revision of the Portuguese Odontopleuridae (Trilobita): Selenopeltis and Primaspis. Comunicações dos Serviços Geológicos de Portugal 68, 213-223.

ROMANO, M. 1991. Trilobites from the Ordovician of Portugal. Palaeontology 34(2), 329-355.

RomAnO, M. \& DiGGENS, J.N. 1974. The stratigraphy and structure of Ordovician and associated rocks around Valongo, north Portugal. Comunicações dos Serviços Geológicos de Portugal 57, 23-50.

SÁ, A.A. 2003. A evoluçăo da cronoestratigrafia do Sistema Ordovícico e a sua aplicação a Portugal. Geonovas 17, $27-34$.

ŠNAJDR, M. 1956. Trilobiti drabovských a letenských vrstev českého ordoviku (Trilobites of the Drabov and Letná beds of 
the Ordovician of Bohemia). Sborník Ústředního ústavu geologického, Oddíl paleontologický 22 (for1955), 477-533.

ŠNAJDR, M. 1957. Classification of the Family Illaenidae (Hawle et Corda) in the Lower Paleozoic of Bohemia. Sborník Ústředního ústavu geologického, Oddíl paleontologický 23 (for 1956), 125-284.

ŠNAJDR, M. 1982. Bohemian representatives of the trilobite genera Kloucekia Delo, Phacopidina Bancroft, Sokhretia Hupé and Dalmanitina Reed. Věstník Ústředního ústavu geologického 57(3), 179-182.

ŠNAJDR, M. 1984. Bohemian Ordovician Odontopleuridae (Trilobita). Sborník geologických věd, Paleontologie 26, 47-82.

ŠNAJDR, M. 1990. Bohemian trilobites. 265 pp. Czech Geological Survey, Prague.

TAUBeR, E.H., Romano, M. \& ReIS, J.M. 1997. The trilobite Actinopeltis (Valongia) wattisoni Curtis, 1961 from the Valongo Formation (Ordovician) of North Portugal. Comunicações do Instituto Geológico e Mineiro 83, 3-16.

TERMIER, G. \& TERMIER, H. 1950. Paléontologie Marocaine. Tome II. Invertébrés de l'Ėre Primaire. Fascicule IV, Annélides, Arthropodes, Échinodermes, Conularides et Graptolithes, 279 pp. Hermann \& Cie, série Actualités Scientifiques et Industrielles, Paris.

VANĚK, J. 1965. New species of the suborder Calymenina Swinneton, 1915 (Trilobita) from the Barrandian area. Sborník geologických věd, Paleontologie 6, 21-37.

VANĚK, J. \& VALÍČEK, J. 2001. New index of the genera, subgen- era, and species of Barrandian trilobites. Part A-B (Cambrian and Ordovician). Palaeontologia Bohemiae 7(1), 1-49.

VANNIER, J. \& SCHALlREUTER, R. 1983. Quadritia (Krutatia) tromelini nov. sp., ostracode du Llandeilo Ibéro-armoricain. Intérêt paléogéographique. Geobios 16(5), 583-599. DOI 10.1016/S0016-6995(83)80036-9

VERNEUIL, E. DE \& BARRANDE, J. 1855. Description des fossiles trouvés dans les terrains Silurien et Dévonien d'Almadén, d'une partie de la Sierra Morena et des Montagnes de Tolède. Bulletin de la Société Géologique de France [2] 12, 964-1025.

VON RAUMER, J.F. \& STAMPFLI, G.M. 2008. The birth of the Rheic Ocean - Early Palaeozoic subsidence patterns and subsequent tectonic plate scenarios. Tectonophysics 461, 9-20. DOI $10.1016 /$ j.tecto.2008.04.012

WHITTARD, W.F. 1940. The Ordovician trilobite fauna of the Shelve-Corndon district, west Shropshire. Part II. Cyclopygidae, Dionidae, Illaenidae, Nileidae. The Annals and Magazine of Natural History 11(6), 129-153.

WhITTARD, W.F. 1960. The Ordovician trilobites of the Shelve inlier, west Shropshire. Part IV. Palaeontographical Society (Monograph) 114 (for 1959), 117-162.

WhITTARD, W.F. 1961. The Ordovician trilobites of the Shelve inlier, west Shropshire. Part VI. Palaeontographical Society (Monograph) 114, 197-228.

ZHOU, Z.-Y. \& ZHEN, Y.-Y. (eds) 2008. Trilobite record of China. 401 pp. Science Press, Beijing. 